\title{
ПОНЯТИЕ ЯЗЫКОВОЙ ХУДОЖЕСТВЕННОЙ КАРТИНЫ МИРА
}

\author{
Хожиева Зарина Бахтияровна \\ $P h D$, дочент кафедры «Лингвистика и английская литература» \\ Узбекский государственный университет мировых языков, \\ Узбекистан, город Ташкент, улииа Kichik Xalqa Yo `li, \\ квартал G-9а, дом 21-а, ИНДЕКС: 100138.
}

\begin{abstract}
Аннотация. В центре внимания автора находится исследование понятия «языковая художественная картина мира», определение основополагающих признаков данного понятия. Основной целью статьи является описание различных подходов и концепций к изучению художественного текста, а также изучение его ключевых особенностей.

Annotation. The author focuses on the study of the concept of "linguistic artistic picture of the world", the determination of the fundamental features of this concept. The main purpose of the article is to describe various approaches and concepts to the study of a literary text, as well as to study its key features.

Ключевые слова: языковая художественная картина мира, художественная картина мира, художественный текст, языковая национальная картина мира, национально-культурная специфика.

Key words: linguistic artistic picture of the world, artistic picture of the world, literary text, linguistic national picture of the world, national - cultural specificity.
\end{abstract}

На современном этапе развития науки в рамках теории языковой картины мира, наибольший интерес представляет проблема исследования «языковой художественной картины мира» (ЯХКМ). Данное понятие приобретает актуальность в связи с тем, что позволяет познать действительность, в частности национальное мышление, мировоззрение, культуру, характер определенного этноса на основе художественного литературного произведения.

Прежде чем перейти к особенностям ЯХКМ, следует рассмотреть художественный текст, поскольку основу ЯХКМ составляет художественный текст, изучение которого в свете художественной картины мира (ХКМ) представляет большой интерес и актуальность. Это обусловлено тем, что художественный текст представляет собой сложное образование, многогранную и многоуровневую организацию, которую возможно постичь совместными усилиями специалистов многих дисциплин, таких как лингвистика, литературоведение, герменевтика, лингвопрагматика, когнитивная лингвистика, лингвокультурология и т.д. Другими словами, изучение художественного текста требует междисциплинарного подхода. В связи с этим существует множество подходов и концепций относительно изучения природы художественного текста. К примеру, в понимании В. Г. Адмони художественный текст - это «возникающее из специфического (эгоцентрического) внутреннего состояния художника душевное, чувственно-понятийное постижение мира в форме речевого высказывания...» $[1$, c.120]. В научных работах Н.А. Николиной основное внимание акцентируется на креативной особенности художественного текста, согласно которой, внутритекстовая действительность «носит условный, как правило, вымышленный характер» $[11$, с.3]. В концепции А.В. Матюшкина художественный текст определяется как символ, который несет «не только информацию, но и особого рода «поэтическое знание» или переживание» [7, с.29]. По В.А. Пищальниковой, он есть «коммуникативно направленное вербальное произведение, обладающее эстетической ценностью, выявленной в процессе его восприятия» [12, с.3].

Таким образом, исходя из вышеуказанных определений, можно охарактеризовать художественный текст как сложное, коммуникативно направленное, эстетически ценностное, эмоционально насыщенное высказывание, служащее для осознания мира. Ключевыми особенностями художественного текста являются его креативность и эстетичность, которые предопределены словесным мастерством писателя, его душевным миром.

Кроме того, немаловажно отметить, что художественный текст, являясь единицей культуры, отражает языковую национальную картину мира (ЯНацКМ) определенного народа. В этом плане интересной является точка зрения Н.С. Болотновой, которая считает, что «текст несет на себе печать культуры определенного этапа в истории общества; культуры определенного народа с его традициями, устоями, менталитетом; неповторимой личности автора» [3, с.115-116]. Художественный текст можно представить, как важнейший способ овладения национальной культурой, источник культурного знания и информации, он есть «плоть и кровь культуры» [6, с.14]. Являясь субъективным изображением объективной реальности, художественный текст отображает национальное видение мира, опыт и знания определенного этноса, его менталитет, национальный характер, традиции, обычаи и ценности. К основным носителям культурной информации относятся языковые средства художественного текста, анализ которых позволяет раскрыть смысл всего текста, осмыслить национальную языковую картину мира данного народа.

В современной лингвистической науке исследование понятия ЯХКМ является малоразработанной проблемой, однако можно отметить диссертационные исследования, в той или иной степени затрагивающие 
данную проблему (С.Б. Аюпова, Ю.Л. Сапожникова) [2; 13]. В исследовании проблемы языковой художественной картины мира основополагающим, на наш взгляд, является изучение понятия «художественная картина мира». Осмысление данного понятия представлено в литературоведческих работах Б.С. Мейлаха, Н.П. Скурту, П.К. Соболева $[8 ; 14 ; 15]$, в которых ХКМ интерпретируется как «воссоздаваемое всеми видами искусства, синтетическое панорамное представление о конкретной действительности тех или иных пространственновременных диапазонов» $[10$, с.120].

В лингвистической литературе наблюдается отождествление понятий ХКМ и ЯХКМ, что является, на наш взгляд, крайне неправомерным. ХКМ охватывает все виды искусства, однако лишь некоторые из них используют язык в качестве инструмента. Следовательно, картина мира, выражаемая языковыми средствами, в частности произведениями художественной литературы должна иметь собственное терминологическое обозначение ЯХКМ. ЯХКМ - это вербализованное представление художественной картины мира, это ХКМ, выраженная посредством языка.

Интерпретируя понятие ЯХКМ как «синкретичное образование, возникающее в результате воплощения художественных смыслов в речи и представляющее собой целостный, многогранный образ художественного мира, создаваемый средствами языка» [2, с.22], исследователи выделяют ряд ее особенностей. Ключевые свойства ЯХКМ определяются, на наш взгляд, основными категориями художественного текста, к которым вслед за многими исследователями (Ю.М. Лотман, И.Р. Гальперин, Г.Г. Молчанова) [5; 4; 9] мы относим: образность, экспрессивность, эмотивность, оценочность, имплицитность, креативность и эстетичность.

Вышеуказанные категориальные признаки получили достаточно полное описание в лингвистической литературе. Однако перечень этих признаков, на наш взгляд, следует дополнить еще одним основополагающим признаком ЯХКМ - национально-культурная специфика, поскольку национально-культурная специфика является сущностным свойством художественных текстов, репрезентирующих ЯХКМ.

\section{Список использованной литературы:}

дмони В.Г. Система форм речевого высказывания. СПб: Наука, 1994. - 151 с.

юпова С.Б. Категории пространства и времени в языковой художественной картине мира (на материале художественной прозы И.С. Тургенева): автореф. дис. ...д-ра. филол. наук. -Уфа, 2012. - 50 с.

олотнова Н.С. Филологический анализ текста. - М.: Флинта: Наука, 2009. - 520 с.

альперин И.Р. Текст, как объект лингвистического исследования. - М.: 1981. - 140 с.

Лотман Ю.М. Структура художественного текста. - М.: Наука 1970. - 220 с.

аслова В.А. Лингвокультурология. - М.: Академия, 2001 - 208 с.

атюшкин А.В. Проблемы интерпретации литературного художественного текста. - Петрозаводск: Изд - во КГПУ, 2007. $-190 \mathrm{c}$.

ейлах Б.С. Процесс творчества и художественное восприятие: комплексный подход: опыт, поиски, перспективы. - М.: Искусство,1985. - 315 с.

олчанова Г.Г. Английский, как неродной: текст, стиль, культура, коммуникация. - М.: Олма Медиа Групп, 2007. $-381 \mathrm{c}$.

икишина И.Ю. Язык, сознание, коммуникация: сб. статей / отв.ред. В.В. Красных, А.И. Изотов. - М.: Макс Пресс, 2002. Вып. 21. -184 c.

иколина Н.А. Филологический анализ текста. - М.: Академия, 2003. - 256 с.

ищальникова В.А. Проблемы лингвоэстетического анализа художественного текста. Барнаул: Изд-во Алт. унта,1984. $-59 \mathrm{c}$.

апожникова Ю.Л. Художественно-языковая картина мира американской провинции (на материале сборника новелл Ш. Андерсона «Уайнсбург, Огайо»): дис. канд. филол. наук. - М.:2003. $185 \mathrm{c}$.

курту Н.П. Искусство и картина мира. - Кишинев: Штиинца, 1990. - 87с.

оболев П.К. Художественная картина мира: ценностная значимость. // Художественное творчество. Л.: Наука, 1986. - C.32 - 36 